\title{
Resveratrol Delivery via Gene Therapy: Entering the Modern Era
}

\author{
Gen Terapisi Yoluyla Resveratrol Illetimi: Modern Çağa Girme
}

\author{
(D) Gurinder SINGH* \\ Micro Labs GmbH, Frankfurt, Germany
}

\begin{abstract}
Resveratrol is a natural compound (an antioxidant) and exhibits numerous therapeutic activities. From a pharmacokinetic perspective, it is unclear whether resveratrol targets the site of action after oral administration because of quick metabolism and excretion that creates doubt on the biological application of the high doses characteristically used for clinical trials. However, these limitations act as a barrier and a challenge for the development of new delivery systems. Recently, gene delivery offers various advantages and has provided treatment options for diseases that are beyond the reach of traditional approaches. The objective of gene therapy for genetic diseases is to achieve durable expression of the therapeutic gene at a level sufficient to alleviate or cure disease symptoms with minimal adverse events. The perception of the molecular and cellular mechanisms steering to therapy and vector-related hindrances have caused in the progress of extremely complex gene delivery with enhanced protection and effectiveness. With the help of gene therapy, it could be possible to target the delivery of resveratrol directly into the host cells and bypass its pharmacokinetic limitations and enhancement of its therapeutic effect. This review is to provide a holistic view of the development of resveratrol gene treatment as a powerful option to treat various deadly diseases.
\end{abstract}

Key words: Gene therapy/delivery, lentivirus, resveratrol, viral vectors

öz

Resveratrol, doğal bir bileșiktir (bir antioksidan) ve çok sayıda terapötik aktivite sergiler. Farmakokinetik bir perspektiften, resveratrolün, klinik deneyler için karakteristik olarak kullanılan yüksek dozlarının biyolojik uygulamasında şüphe yaratan hızlı metabolizma ve atılım nedeniyle oral uygulamadan sonra etki alanını hedefleyip hedeflemediği açık değildir. Bununla birlikte, bu sınırlamalar, yeni dağıım sistemlerinin geliştirilmesi için bir engel ve zorluk teşkil etmektedir. Son zamanlarda, gen dağıtımının çeşitli avantajlar sağladığı ve geleneksel yaklaşımların ulaşamayacağı hastalıklar için tedavi seçenekleri sağladığı görülmüştür. Genetik hastalıklar için gen terapisinin amacı, minimum yan etki ile hastalık semptomlarını iyileștirmek veya iyileștirmek için yeterli bir seviyede terapötik genin kalıcı ifadesini elde etmektir. Tedaviye yönlendiren moleküler ve hücresel mekanizmaların algılanması ve vektöre bağı engeller, gelişmiş koruma ve etkililik ile aşırı derecede karmaşık gen dağıımının ilerlemesine neden olmuștur. Gen terapisinin yardımıyla, resveratrolün doğrudan konakçı hücrelere verilmesini hedeflemek ve farmakokinetik sınırlamalarını ve terapötik etkisinin arttırılmasını atlamak mümkün olabilir. Bu derleme, çeşitli ölümcül hastalıkları tedavi etmek için güçlü bir seçenek olarak resveratrol gen tedavisinin gelişiminin bütünsel bir görünümünü sağlamaktır.

Anahtar kelimeler: Gen tedavisi/doğum, lentivirüs, resveratrol, viral vektörler

\section{INTRODUCTION}

Resveratrol is a natural compound separated from Veratrum grandiflorum plant, in the 1940s.' It is originated in various plants, particularly peanuts, grapes, and berries. Recently, resveratrol enticed several research considerations because of its stimulating pharmacological ability. 2,3 Some clinical studies state that resveratrol can avert and slow down the evolution of an extensive variety of illnesses including cardiovascular disease ${ }^{4}$ and HIV/AIDS. 5,6 Nevertheless, beneficial applications of resveratrol are inadequate by virtue of its low biological half-life and rapid metabolism. ${ }^{7}$ In vivo data designate that the resveratrol bioavailability is practically zero, which mold distrust on the high doses usually used in vitro. ${ }^{8}$ It is expressed that after an oral administration, the resveratrol bioavailability in systemic circulation and in tissues is very less due to raid 
metabolism. ${ }^{9}$ Correspondingly, in the case of nanocarriers, it is a promising approach to be a potential bio-nanocarrier for the drug delivery system. Some recent reports depicted that nanocarriers (to some extent) might be an appropriate transporter for oral administration and released the drug in a controlled manner. ${ }^{10}$ Thus, there is an urgent need to develop suitable systems of delivering resveratrol at a site of action, which can protect from diseases and give new hope in the treatment options. Such a system called "gene therapy" is widely available and is under clinical trial consideration."

Gene therapy is the delivery of a genetic substances to a patient to target tissues or cells to treat a disease..$^{2}$ Gene therapy is specifically designed to alter the expression of a gene or to modify the biological attributes of cells for beneficial use.13,14 In the future, this practice might permit specialists to address a syndrome by implanting a gene into a patient's cells in lieu of other drug delivery approaches. ${ }^{15}$ It includes the use of nucleic acids for the therapy, heals or preclusion of patient illness. ${ }^{16}$ Genetic material is intended to introduce into cells to redress for irregular genes and to produce a beneficial protein. This treatment is capable of presenting a usual copy of the gene to restore the function of the protein if a metamorphosed gene produces a required defective or lost protein. ${ }^{15}$ Gene therapy can operate by numerous mechanisms viz. a virus-infected gene can be exchanged with a healthy gene, inactivate the gene caused by disease which is not working appropriately, and to treat a disease, inserting a modified gene into the body.14,15

Several approaches for current gene delivery have been developed and classified as viral vectors, non-viral vectors (chemical and physical), and vaccination. ${ }^{17}$ Viral vectorbased gene delivery systems can deliver genetic material, the most widely used ones are depicted in Table 1. A gene that is introduced directly into a cell typically does not work. Therefore, a transporter named as a vector is hereditarily/ genetically engineered to transport the gene. ${ }^{18}$ Specific viruses are frequently used as vectors in view of the fact that they may transport the new gene by infecting the cell. The viruses are altered so they cannot induce disease when used in patients. 15,19 Retroviruses consolidate their genetic material (including the new gene) into the cell without altering the cell's own genetic material. ${ }^{20}$
The vector can be injected intravenously, in the body it is then occupied by specific cells. Consecutively, in the laboratory a sample of the patient's cells can be withdrawn and revealed. The cells comprising the vector are then returned to the patient. If the therapy is successful, the novel gene transported by the vector will lead to the production of a functioning protein.15,21,22 There is a possibility where vector-resveratrol can be delivered to the cells or particular tissues to treat various diseases and enhance the therapeutic potential of resveratrol. Recent reports on resveratrol gene therapy have fascinated attention with 872 articles/manuscripts available on the PubMed portal between 1993 and 2020 are illustrated in Figure 1. ${ }^{23}$

\section{SCOPE OF THE REVIEW}

This review attempted on the present inventions of resveratrol gene therapy to augment its therapeutic effect. As per literature survey, this is the first review analysis on resveratrol gene therapy as literature lacks such review data.

\section{DELIVERY OF LENTIVIRAL VECTORS IN GENE THERAPY}

Gene therapy carries an excessive possibility for addressing an abundant various diseases, some of which are not curable. ${ }^{22} \mathrm{~A}$ virus called a vector to transport/deliver therapeutic genes into cells is a approach. Viral vectors are expressly altered so they cannot replicate/multiply within the target cells. ${ }^{24,25}$ Viruses are compact parasites with either an RNA or DNA genome that are enclosed by a defensive protein coat and transmission their genetic material to infected cells. Lentivirus is a class of retroviruses that causes deadly diseases categorized by long incubation periods. Lentiviral vectors (LVs), derived from HIV, have been broadly examined and considered. ${ }^{26,27}$ To accurate main immunodeficiencies and hemoglobinopathies, selfinactivating (third generation) LV has been used in several medical studies to insert genes into hematopoietic stem cells. ${ }^{28}$ Because of LV capability to further proficiently transform nonproliferating cells, it has become predominantly attractive for clinical demands. ${ }^{29}$ LV present exceptional benefits over diverse gene delivery systems, specifically the capability to incorporate transgenes into the genome of dividing and non-dividing cells. ${ }^{27}$

Table 1. Viral vector for gene delivery

\begin{tabular}{llll}
$\begin{array}{l}\text { Gene delivery method (viral } \\
\text { vectors) }\end{array}$ & Functional components & Features & Features \\
\hline Retrovirus & RNA & High efficiency & Random integration \\
\hline Lentivirus & RNA & $\begin{array}{l}\text { High efficiency } \\
\text { sustained gene expression }\end{array}$ & Random integration \\
\hline Adenovirus & Double stranded DNA & $\begin{array}{l}\text { High efficiency, } \\
\text { sustained gene expression, }\end{array}$ & Integration may happen \\
\hline Adenovirus associated virus & Single stranded DNA & $\begin{array}{l}\text { Non-pathogenic, } \\
\text { sustained gene expression }\end{array}$ & small volume of transgene \\
\hline Herps simplex virus & Double stranded DNA & $\begin{array}{l}\text { No integration } \\
\text { sustained gene expression }\end{array}$ & Small transduction efficacy
\end{tabular}




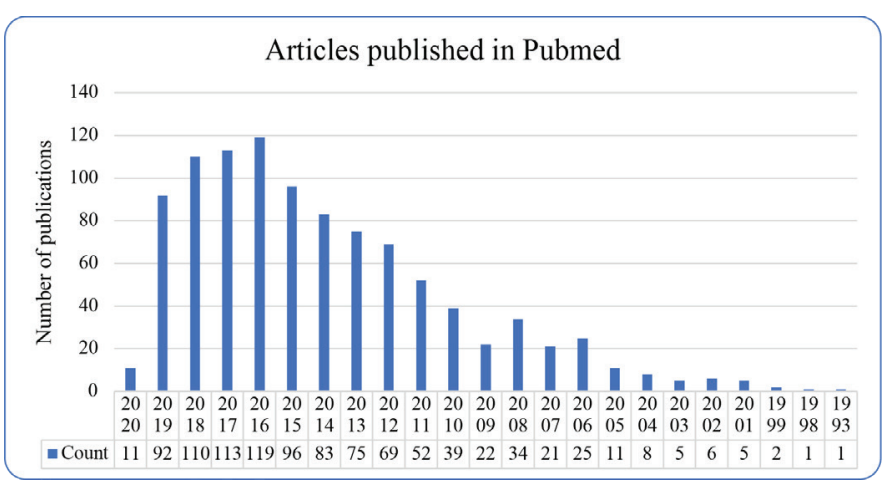

Figure 1. Graphical illustration of publications year wise on resveratrol gene therapy/expression over the last 28 years

Non-integrating vectors, such as adeno-associated viruses (AAV) transduce inactive or slowly dividing cells, as they can be rapidly vanished from dividing cells.30 The cumulative number of fruitful clinical studies has pushed the progress of gene transfer techniques in various diseases, such as cancer, ${ }^{31}$ neurodegenerative, ${ }^{32}$ diabetes, ${ }^{33}$ HIV/AIDS, ${ }^{34}$ and metabolic liver diseases. ${ }^{35}$

\section{EX VIVO GENE TREATMENT}

Ex vivo gene treatment includes the collecting of the patient cells accompanied by following viral transduction ex vivo in a lab by a virus transporting the therapeutic gene. The cells have been transformed and got back to the patient. Contrary, in vivo treatment comprises the inoculation of a virus transporting the healing gene straight into a body. ${ }^{36}$ Lentivirus, adenovirus, retrovirus and $A A V$ are the utmost usual viral vectors exploit for ex vivo and in vivo gene therapy. AAV has numerous exceptional characteristics that turn it a superlative vector for gene delivery. Gene expression for a long period, AAV vectors may dwell for the complete lifecycle of a given cell is highly recommended and used, which reduces the amount of therapy. Contrarily, to carry on a small period (days to weeks) gene expression, adenovirus is classically used in circumstances where the essential level of expression is required. ${ }^{37,38}$

\section{RESVERATROL GENE DELIVERY}

Resveratrol performs a valuable character in the inhibition and in the progress of long-lasting diseases such as cardiovascular, cancers, liver disorders, diabetes, neurodegeneration, and many more. The idea of gene treatment is an investigational system that uses genes to cure or stop disease and viruses. The non-existence of appropriate therapy has converted a rational basis for encompassing the possibility of gene therapy. ${ }^{38,39}$ Resveratrol gene therapy presents numerous advantages such as, the impact of a treatment is long-lasting and less time consuming and can eliminate diseases and strengthen the quality of life. ${ }^{39,40}$ The strategy of new resveratrol gene therapy is to target oxidative stress and redox imbalance could signify imperative beneficial methods towards neurological diseases. ${ }^{41}$ Further, resveratrol gene therapy could bring the solution of resveratrol pharmacokinetics limitations which enhances its therapeutic effect.

\section{RESVERATROL GENE THERAPY IN CANCER}

Cancer is one of the utmost frequently identified diseases and establishes a substantial illness globally. However, countless efforts have been made to find a therapy but remains an eminent source of mortality in individuals, and effectual therapy/cure remains a terrific challenge. ${ }^{42,43}$ Notwithstanding numerous new developments in diagnosis and investigation, the cancer endurance amount has not enhanced. Recently, novel/targeted treatments have developed, providing better results for cancer patients. Existing cancer treatments include chemotherapy, nano-carriers, radiation, and surgery, have boundaries subsequent from the progress of resistance to the therapy. ${ }^{44}$ Recently, a substantial volume of investigation has designated that consumption of resveratrol may prevent the development of cancer. ${ }^{43}$ Since then researchers have started a resveratrol gene therapy against cancer. Izquierdo-Torres et al. ${ }^{45}$ investigated the epigenetic mechanisms of resveratrolinduced ATP2A3 up-regulation. The outcomes designated that approximately $50 \%$ decreased in HDAC activity and nuclear HDAC2 expression was observed. Further finding suggests that HAT activity can be increased with resveratrol therapy; nevertheless, pharmacological hindrance of p300, one of the main HATs, have not shown important impacts in resveratrol gene expression. ${ }^{45}$ In another study, authors reported the exceptional properties of resveratrol, if they could empower viral vectors, used in gene therapy to deliver genes, to enter blood stem cells more easily. The provisional co-application of resveratrol trimer caraphenol $\mathrm{A}$ augments $L V$ gene delivery productivity to primate hematopoietic stem. Results showed that the alteration of important immune constraint factors is a capable and non-toxic method to enhance resveratrol LVmediated gene therapy.42 Shi et al. ${ }^{46}$ reproduced natural or synthetic Egr-1 promoter upstream of GADD $45 \alpha$ cDNA to produce a suicide gene therapy vector. Authors analysed that synthetic promoter that comprises of CArG elements important in the Egr-1 promoter to initiative the expression of GADD $45 \alpha$ following resveratrol therapy. Results affirmed that both promoters were capable of activating the expression of GADD $45 \alpha$ with resveratrol, and consequently directed to the abolition of cell multiplication and apoptosis. ${ }^{46}$ Novel peptidecationic lipid (CDO14) liposome was developed to combine the delivery of resveratrol and $p 53$ gene for gene transfer capability of resveratrol liposomes and antitumor effect on breast cancer cells was examined. MTT assay demonstrated that combination therapy of resveratrol and p53 had greater progress restraint on breast cancer cells. ${ }^{47}$

Xiao et al. ${ }^{48}$ investigated that resveratrol might augment intercellular transmission at the opening intersections in CBRH7919 hepatoma cells and thus boost the spectator killing impact of GCV on CBRH7919TK cells. The outcomes determine that co-treatment of resveratrol and GCV in tumor-bearing mice with CBRH7919TK and CBRH7919WT cells resulted in a momentous reduction in the size and mass of the tumor..$^{48}$ DNA methylation on human multidrug resistance gene 1 (MDR1) was scrutinized and the effect of resveratrol and prednisolone on MDR1 gene agent in the CCRF-CEM cell line was appraised. 
Results suggested that in spite of a substantial influence to decrease the MDR1 expression, methylation form was not later by resveratrol and prednisolone, which needs additional studies to understand the mechanisms. ${ }^{49}$ Bickenbach et al. ${ }^{50}$ stated that resveratrol stimulates the cancer gene therapy vector Ad.Egr. TNF and in vitro prevention of SIRT1 activity did not revoke the resveratrol mechanism of Egr-1 expression. The authors concluded that control of transgene expression via resveratrol stimulation of Egr-1 might spread the use of Ad. Egr. TNF to candidate indignant of cytotoxic treatment and provide a new means for the progress of further gene therapies. ${ }^{50}$

\section{RESVERATROL GENE THERAPY IN OSTEOGENESIS IMPERFECTA}

Osteogenesis imperfecta is an intermittent genetic disorder of bone and connective tissue defined by bone brittleness which results in bones that breakdown effortlessly. ${ }^{51}$ It has been reported that SIRT1 gene as an applicant for therapy of osteogenesis and augments adipogenesis. ${ }^{52}$ Some studies speculated that resveratrol may boost osteogenesis through SIRT1, but the mechanism stays uncertain. Tseng et al. ${ }^{53}$ investigated and found that resveratrol can modify and promote natural osteogenesis in human mesenchymal stem cells and upregulated the expression of osteo-lineage genes RUNX2. Further, resveratrol triggered SIRT1 action and boosted FOX03A protein expression, recognised goal of SIRT1. Ectopic overexpression plays a vital character for SIRT1FOX03A complex in governing resveratrol-induced RUNX2 gene transcription. In the end, these results designated that the resveratrol upregulating RUNX2 gene expression via the SIRT1/ FOX03A. ${ }^{53}$ The impacts of resveratrol on trauma from occlusioninduced bone loss in mice was investigated. Resveratrol was administered for around 15 days and the impact on bone resorption was evaluated. In vitro outcome of resveratrol was assessed on RAW 264.7 cells and macrophages into osteoclastic cells. The authors concluded that resveratrol expressively declined the bone loss and blocked the raised expression of osteoclastogenesis-related gene in periodontal ligament tissue by trauma from occlusion. ${ }^{54}$ Zhou et al. ${ }^{55}$ studied the resveratrol osteogenic effect on mesenchymal stem cells, AMP-activated protein kinase and reactive oxygen species signaling pathway. Results demonstrated that resveratrol therapy undoubtedly boosted the osteogenic-related genes expression prevented the reactive oxygen species, whereas AMP-activated protein kinase expression was improved by resveratrol. ${ }^{55}$ The impact of resveratrol on the gene expression of osteogenic markers was investigated. Two calvarial defects were created and rats were administered resveratrol $10 \mathrm{mg} / \mathrm{kg}(\mathrm{n}=15)$ for 1 month and placebo (control group, $n=15$ ) and sacrificed. Histomorphometric analysis was performed on one calvarial defects and the tissue was collected for mRNA quantification of bone morphogenetic protein. Results confirmed resveratrol augmented the repair of bone defects and may boost the gene expression of significant osteogenic markers. ${ }^{56}$

\section{RESVERATROL GENE THERAPY IN DIABETES}

Diabetes mellitus is a permanent metabolic syndrome and has been growing gradually worldwide. It is a collection of metabolic diseases categorized by hyperglycemia resulting from shortcomings in insulin secretion. Long-lasting hyperglycemia is related to injury and failure of organs. ${ }^{57}$ Published data demonstrated that inhibition of beta-cell autoimmunity is a precise gene therapy for stoppage of type 1 diabetes, while enhancement in insulin sensitivity of peripheral tissues is an exact gene therapy for type 2 diabetes. ${ }^{58}$ Welsh, suggested that progress in gene transfer methods are checked on the pancreatic insulin manufacturing beta-cell. If effective and harmless vectors are existing that transduce beta-cells in vivolex vivo, autoimmune beta-cell devastation in type 1 diabetes might be prohibited and gene delivery will defend the rest beta-cell mass in a pre-diabetic patient at a serious threat of becoming diabetic from autoimmune obliteration. ${ }^{59}$ Sarkar et al. ${ }^{60}$ investigated the impacts of resveratrol and mangiferin on biochemical parameters of PPAR $\gamma$ and FALDH gene expression in adipose tissue of streptozotocin nicotinamide diabetic rats. Rats were analysed after giving an oral dose of resveratrol (40 mg/kg), mangiferin (40 mg/kg) and glibenclamide (0.6 $\mathrm{mg} / \mathrm{kg}$ ). Results portrayed that resveratrol and mangiferin to streptozotocin nicotinamide induced diabetic rats exhibited the noteworthy defensive outcome on all the biochemical parameters. Additionally, both resveratrol and mangiferin presented substantial augmentation of PPAR $\gamma$ and FALDH gene expression in rat adipose tissue related to non-treated rats. ${ }^{60}$

\section{RESVERATROL GENE THERAPY IN LIVER DISORDERS}

Studies verified that resveratrol has numerous therapeutic effects on liver disorders. Resveratrol considerably decreased fat deposition and protect the liver from chemical and alcohol injury. It may augment glucose metabolism and lipid profile and reduce liver fibrosis and steatosis. ${ }^{61}$ Azirak et al. ${ }^{62}$ studied the impact of resveratrol on the fatty acid synthase gene expression towards the adverse effects of risperidone in rat liver. The resveratrol therapy expressively diminished weight gain and the fatty acid synthase gene expression level improved pointedly in the RSV1 group. Findings concluded that treatment with resveratrol could guard liver tissue towards the undesirable effects of risperidone over fatty acid synthase gene expression. ${ }^{62}$

\section{CONCLUSION}

Conventional resveratrol delivery systems display poor absorption and pose a daunting challenge for the existing methods for bioavailability limitations. Considering these obstacles, the nanocarriers are being measured as extraordinary inventions to conquer these glitches of deprived and inconsistent bioavailability, but it is unclear whether this entity targets the site of action after oral administration. Recently, resveratrol gene therapy is an auspicious option for numerous diseases (HIV/AIDS, cancer, cardiovascular, 
liver disorders, and infections). For example, resveratrol may act as an anticancer agent for breast cancer by influencing the epigenetics of breast cancer-associated genes. Similarly, resveratrol influences other disease-associated genes. There is a possibility where vector-resveratrol can be delivered to the cells or particular tissues to treat various diseases and enhance the therapeutic potential of resveratrol which both directly and indirectly overcome the pharmacokinetic limitations. The huge volume of preclinical findings in support of resveratrol's use as chemotherapeutic agents warrants further clinical studies. With gene therapy, resveratrol and its by-products may lead to treatments in diseases as an attempt to decline or eradicate the reservoir of disease-ridden cells with the anticipation of finally healing a patient. This method remains dangerous and is under testing to ensure that it will be safe and efficient. The cost of these therapies has been highlighted as a subject that may hamper the growth of gene therapies as commercially feasible treatments. The anticipation is that the sustained benefits of these one-time treatments will validate the excessive costs. Beyond that, the administration bodies of the developed nations and authorities like Food and Drug Administration/World Health Organization/ European Medicines Agency should take a step to initiate these therapies with courage and expectation otherwise these treatments might no longer be acceptable solitary as a substitute therapy for incurably sick individuals who failed conventional therapies. Further studies are obligatory to elucidate whether resveratrol gene therapy has any effect on the normal function and shows any therapeutic potential to the number of incurable diseases.

\section{ACKNOWLEDGMENTS}

I am grateful to Prof. Param Sharma for their valuable advice and support in the preparation and editing of this review.

Conflict of interest: The author declares no conflicts of interest and there is no association between the contents of this review and Micro Labs GmbH and no confidential information of the latter is disclosed.

\section{REFERENCES}

1. Takaoka MJ. Of the phenolic substances of white hellebore (Veratrumgrandiflorum Loes. fil). J Faculty Sci Hokkaido Im Univ. 1940;3:1-16.

2. Singh G, Pai RS. Recent advances of resveratrol in nanostructured based delivery systems and in the management of HIV/AIDS. J Control Release. 2014;194:178-188.

3. Rauf A, Imran M, Butt MS, Nadeem M, Peters DG, Mubarak MS. Resveratrol as an anti-cancer agent: a review. Crit Rev Food Sci Nutr. 2018;58:1428-1447.

4. Dyck GJB, Raj P, Zieroth S, Dyck JRB, Ezekowitz JA. The effects of resveratrol in patients with cardiovascular disease and heart failure: a narrative review. Int J Mol Sci. 2019;20:904.

5. Heredia A, Davis C, Amin MN, Le NM, Wainberg MA, Oliveira M, Deeks SG, Wang LX, Redfield RR. Targeting host nucleotide biosynthesis with resveratrol inhibits emtricitabine-resistant HIV-1. AIDS. 2014;28:317323.

6. James JS. Resveratrol: why it matters in HIV. AIDS Treat News. 2006:3-5.

7. Chimento A, De Amicis F, Sirianni R, Sinicropi MS, Puoci F, Casaburi I, Saturnino C, Pezzi V. Progress to improve oral bioavailability and beneficial effects of resveratrol. Int J Mol Sci. 2019;20:1381.

8. Walle T. Bioavailability of resveratrol. Ann N Y Acad Sci. 2011;1215:9-15.

9. Gambini J, López-Grueso R, Olaso-González G, Inglés M, Abdelazid K, Alami MEL, Bonet-Costa V, Borrás C, Viña J. Resveratrol: distribution, properties and perspectives. Rev Esp Geriatr Gerontol. 2013;48:79-88.

10. Neves AR, Lúcio M, Martins S, Lima JL, Reis S. Novel resveratrol nanodelivery systems based on lipid nanoparticles to enhance its oral bioavailability. Int J Nanomedicine. 2013;8:177-187.

11. https://www.fda.gov/regulatory-information/search-fda-guidancedocuments/considerations-design-early-phase-clinical-trials-cellularand-gene-therapy-products (Accessed date: 24/05/2020).

12. Anguela XM, High KA. Entering the modern era of gene therapy. Annu Rev Med. 2019;70:273-288.

13. Long Term Follow-Up After Administration of Human Gene Therapy Products; Draft Guidance for Industry, July 2018. (Accessed date: 24/05/2020).

14. https://www.fda.gov/vaccines-blood-biologics/cellular-gene-therapyproducts/what-gene-therapy\#footnote1 (Accessed date: 24/05/2020).

15. https://ghr.nlm.nih.gov/primer/therapy/genetherapy (Accessed date: 24/05/2020).

16. Kaufmann KB, Büning $H$, Galy A, Schambach A, Grez M. Gene therapy on the move. EMBO Mol Med. 2013;5:1642-1661.

17. Wirth T, Parker N, Ylä-Herttuala S. History of gene therapy. Gene 2013;525:162-169.

18. Brody H. Gene Therapy. Nature 2018;564:565.

19. High KA, Roncarolo MG. Gene Therapy. N Engl J Med. 2019;381:455464.

20. Pederson T. Gene Therapy Now? FASEB J. 2018;32:1731-1732.

21. Smith $\mathrm{ClE}$, Blomberg P. Gene therapy - from idea to reality. Lakartidningen. 2017;114:EWYL.

22. Athanasopoulos T, Munye MM, Yáñez-Muñoz RJ. Nonintegrating gene therapy vectors. Hematol Oncol Clin North Am. 2017;31:753-770.

23. https://pubmed.ncbi.nlm.nih.gov/?term=resveratrol+gene+therapy (Accessed date: 24/05/2020).

24. https://www.fda.gov/vaccines-blood-biologics/biologics-researchprojects/cell-specific-and-gene-specific-targeting-gene-therapyvectors (Accessed date: 24/05/2020).

25. Milone MC, O'Doherty U. Clinical use of lentiviral vectors. Leukemia. 2018;32:1529-1541.

26. Benskey MJ, Manfredsson FP. Lentivirus production and purification. Methods Mol Biol. 2016:1382:107-114.

27. McCarron A, Donnelley M, McIntyre C, Parsons D. Challenges of up-scaling lentivirus production and processing. J Biotechnol. 2016;240:23-30.

28. Hauber I, Beschorner N, Schrödel S, Chemnitz J, Kröger N, Hauber J, Thirion C. Improving lentiviral transduction of $\mathrm{CD}_{3} 4^{+}$hematopoietic stem and progenitor cells. Hum Gene Ther Methods. 2018;29:104-113. 
29. McGarrity GJ, Hoyah G, Winemiller A, Andre K, Stein D, Blick G, Greenberg RN, Kinder C, Zolopa A, Binder-Scholl G, Tebas P, June CH, Humeau LM, Rebello T. Patient monitoring and follow-up in lentiviral clinical trials. J Gene Med. 2013;15:78-82.

30. Chen YH, Keiser MS, Davidson BL. Viral vectors for gene transfer. Curr Protoc Mouse Biol. 2018:8:e58.

31. Libutti SK. Recording 25 years of progress in cancer gene therapy. Cancer Gene Ther. 2019;26:345-346.

32. Sudhakar V, Richardson RM. Gene therapy for neurodegenerative diseases. Neurotherapeutics. 2019;16:166-175.

33. Stafeev YS, Menshikov MY, Parfyonova YV. Gene therapy of type 2 diabetes mellitus: state of art. Ter Arkh. 2019;91:149-152.

34. Xiao Q, Guo D, Chen S. Application of CRISPR/Cas9-based gene editing in HIV-1/AIDS therapy. Front Cell Infect Microbiol. 2019;9:69.

35. Zabaleta N, Hommel M, Salas D, Gonzalez-Aseguinolaza G. GeneticBased approaches to inherited metabolic liver diseases. Hum Gene Ther. 2019;30:1190-1203.

36. https://www.jyi.org/2009-january/2017/10/2/evaluation-of-theclinical-success-of-ex-vivo-and-in-vivo-gene-therapy\#(Accessed date: $24 / 05 / 2020$ ).

37. Templeton NS. Gene and Cell Therapy: Therapeutic Mechanisms and Strategies. $4^{\text {th }}$ ed. New York: CRC Press; 2008.

38. Jafarlou M, Baradaran B, Saedi TA, Jafarlou V, Shanehbandi D, Maralani M, Othman F. An overview of the history, applications, advantages, disadvantages and prospects of gene therapy. J Biol Regul Homeost Agents. 2016;30:315-321.

39. http://www.biolyse.ca/gene-therapy-pros-and-cons/ (Accessed date: 25/05/2020).

40. https://futureofworking.com/6-advantages-and-disadvantages-ofgene-therapy/ (Accessed date: 25/05/2020).

41. Navarro-Yepes J, Zavala-Flores L, Anandhan A, Wang F, Skotak M, Chandra N, Li M, Pappa A, Martinez-Fong D, Del Razo LM, QuintanillaVega B, Franco R. Antioxidant gene therapy against neuronal cell death. Pharmacol Ther. 2014;142:206-230.

42. Ozog S, Timberlake ND, Hermann K, Garijo O, Haworth KG, Shi G, Glinkerman CM, Schefter LE, D'Souza S, Simpson E, Sghia-Hughes G, Carillo RR, Boger DL, Kiem HP, Slukvin I, Ryu BY, Sorrentino BP, Adair JE, Snyder SA, Compton AA, Torbett BE. Resveratrol trimer enhances gene delivery to hematopoietic stem cells by reducing antiviral restriction at endosomes. Blood. 2019;134:1298-1311.

43. Ko JH, Sethi G, Um JY, Shanmugam MK, Arfuso F, Kumar AP, Bishayee A, Ahn KS. The role of resveratrol in cancer therapy. Int J Mol Sci. 2017;18:2589.

44. Granier C, Karaki S, Roussel H, Badoual C, Tran T, Anson M, Fabre E, Oudard S, Tartour E. Cancer immunotherapy: rational and recent breakthroughs. Rev Med Interne 2016;37:694-700.

45. Izquierdo-Torres E, Hernández-Oliveras A, Meneses-Morales I, Rodríguez G, Fuentes-García G, Zarain-Herzberg Á. Resveratrol upregulates ATP2A3 gene expression in breast cancer cell lines through epigenetic mechanisms. Int J Biochem Cell Biol. 2019;113:37-47.

46. Shi Q, Geldenhuys W, Sutariya V, Bishayee A, Patel I, Bhatia D. CArGdriven GADD $45 \alpha$ activated by resveratrol inhibits lung cancer cells. Genes Cancer. 2015;6:220-230.
47. Xu X, Liu A, Bai Y, Li Y, Zhang C, Cui S, Piao Y, Zhang S. Co-delivery of resveratrol and $\mathrm{p} 53$ gene via peptide cationic liposomal nanocarrier for the synergistic treatment of cervical cancer and breast cancer cells. J Drug Deliv Sci Technol. 2018;51:746-753.

48. Xiao J, Wang X, Wu Y, Zhao Q, Liu X, Zhang G, Zhao Z, Ning Y, Wang K, Tan Y, Du B. Synergistic effect of resveratrol and HSV-TK/GCV therapy on murine hepatoma cells. Cancer Biol Ther. 2019;20:183-191.

49. Zadi Heydarabad M, Nikasa M, Vatanmakanian M, Azimi A, Farshdousti Hagh M. Regulatory effect of resveratrol and prednisolone on MDR1 gene expression in acute lymphoblastic leukemia cell line (CCRF-CEM): an epigenetic perspective. J Cell Biochem. 2018;119:4890-4896.

50. Bickenbach KA, Veerapong J, Shao MY, Mauceri HJ, Posner MC, Kron SJ, Weichselbaum RR. Resveratrol is an effective inducer of CArGdriven TNF-alpha gene therapy. Cancer Gene Ther. 2008;15:133-139.

51. Brizola E, Felix T, Shapiro J. Pathophysiology and therapeutic options in osteogenesis imperfecta: an update. Res Rep Endocr Disord. 2016;6:17-30.

52. Li M, Yan J, Chen X, Tam W, Zhou L, Liu T, Pan G, Lin J, Yang H, Pei M. He F. Spontaneous up-regulation of SIRT1 during osteogenesis contributes to stem cells' resistance to oxidative stress. J Cell Biochem. 2018;119:4928-4944.

53. Tseng PC, Hou SM, Chen RJ, Peng HW, Hsieh CF, Kuo ML, Yen ML. Resveratrol promotes osteogenesis of human mesenchymal stem cells by upregulating RUNX2 gene expression via the SIRT1/FOXO3A axis. J Bone Miner Res. 2011;26:2552-2563.

54. Matsuda Y, Minagawa T, Okui T, Yamazaki K. Resveratrol suppresses the alveolar bone resorption induced by artificial trauma from occlusion in mice. Oral Dis. 2018;24:412-421.

55. Zhou $T$, Yan $Y$, Zhao $C, X u Y$, Wang $Q, X u$ N. Resveratrol improves osteogenic differentiation of senescent bone mesenchymal stem cells through inhibiting endogenous reactive oxygen species production via AMPK activation. Redox Rep. 2019;24:62-69.

56. Casarin RC, Casati MZ, Pimentel SP, Cirano FR, Algayer M, Pires PR, Ghiraldini B, Duarte PM, Ribeiro FV. Resveratrol improves bone repair by modulation of bone morphogenetic proteins and osteopontin gene expression in rats. Int J Oral Maxillofac Surg. 2014;43:900-906.

57. American Diabetes Association. Diagnosis and classification of diabetes mellitus. Diabetes Care. 2014;37(Suppl 1):S81-S90.

58. Yamaoka T. Gene therapy for diabetes mellitus. Curr Mol Med. 2001;1:325-337.

59. Welsh N. Gene therapy in diabetes mellitus: promises and piffalls. Curr Opin Mol Ther. 1999;1:464-470.

60. Sarkar P, Bhowmick A, Kalita MC, Banu S. Effects of resveratrol and mangiferin on PPAR $\gamma$ and FALDH gene expressions in adipose tissue of streptozotocin-nicotinamide-induced diabetes in rats. J Diet Suppl. 2019;16:659-675.

61. Faghihzadeh F, Hekmatdoost A, Adibi P. Resveratrol and liver: a systematic review. J Res Med Sci. 2015;20:797-810.

62. Azirak S, Bilgic S, Tastemir Korkmaz D, Guvenc AN, Kocaman N, Ozer $M K$. The protective effect of resveratrol against risperidone-induced liver damage through an action on FAS gene expression. Gen Physiol Biophys. 2019;38:215-225. 